\title{
Polycyclic Aromatic Hydrocarbon (PAHs) Analyses in Marine Tissues Using Accelerated Solvent Extraction (ASE) in Tandem with In-Cell Purification and GC-MS
}

\author{
Camilla V. G. Pinheiro, ${ }^{a}$ Renato S. Carreira ${ }^{\circledR * a}$ and Carlos G. Massone ${ }^{\circledR a}$ \\ ${ }^{a}$ Laboratório de Estudos Marinhos e Ambientais (LabMAM), Departamento de Química, \\ Pontifícia Universidade Católica do Rio de Janeiro (PUC-Rio), 22451-900 Rio de Janeiro-RJ, Brazil
}

\begin{abstract}
The aim of this research was the replacement of conventional sample extraction techniques for polycyclic aromatic hydrocarbons (PAH) in tissue samples for a reliable, fast and ecofriendly procedure. The method was developed using a pressurized solvent extraction method and assessing two different standard reference materials (fish and mussel) and freeze-dried and fortified sardine samples (Sardinella sp.). Five different extraction procedures were evaluated and the best performance comprised $1 \mathrm{~g}$ of lyophilized tissue, $5 \mathrm{~g}$ of deactivated (5\%) silica, a dichloromethane:methanol $(4: 1 \mathrm{v} / \mathrm{v})$ mixture, a temperature of $80^{\circ} \mathrm{C}$, three cycles, $10 \mathrm{~min}$ of static time and $90 \mathrm{~s}$ of purge time. The method selected following these tests was further validated through the analysis of nine replicates of the National Institute of Standard and Technology (NIST) reference material No. 2976, resulting in an effective recovery of $83 \pm 14 \%$. The means and uncertainties attained for each PAH were equivalent to those of the reference material, corroborating the reliability of the developed method. A shorter processing time, less use of solvents and reagents and lower extract manipulation produced an effective method aligned with green-chemistry guidelines.
\end{abstract}

Keywords: PAH analysis, tissue samples, method development, accelerated solvent extraction, green chemistry

\section{Introduction}

The production and final disposal of anthropogenic waste in aquatic systems have increased in the last decades. ${ }^{1}$ The myriad of contaminants contained in these effluents are one of the major drivers of ocean pollution, causing loss of biodiversity and decreasing their capacity to provide ecological services, among other effects, which ultimately endanger human health., ${ }^{2,3}$ Polycyclic aromatic hydrocarbons (PAHs), a group of more than one hundred compounds with at least two fused and thermodynamically stable aromatic rings, are of particular environmental concern, as they are toxic, persistent and ubiquitous in aquatic systems. ${ }^{4}$ PAHs are derived from the incomplete combustion of organic materials and fossil fuel or from direct petroleum inputs ${ }^{5}$ and may bioaccumulate throughout the trophic chain, causing adverse biological effects. ${ }^{6-8}$ PAHs exposure is known to display the potential to cause tumors, fertility problems and birth defects, ${ }^{9,10}$ among other outcomes.

Validated data on PAHs and other organic contaminants in environmental matrices, such as water, sediments, atmosphere and biota, are a requirement for fate or exposure

*e-mail: carreira@puc-rio.br assessments concerning (organic) micropollutants in aquatic systems. ${ }^{11}$ Particularly, PAH analyses in animal tissues (i.e., flesh, liver, blubber) is challenging due to matrix complexity (e.g., high fat contents) and the low limits of detection and quantification required to detect toxic chemicals at $\mathrm{ng} \mathrm{g}^{-1}$ (wet weight) levels. ${ }^{12}$ The effort, however, is worthy, since consistent environmental assessments may reveal chemical exposure patterns and indicate compound biomagnification/bioaccumulation potentials, as well as exposure and health risks to humans through fish consumption. ${ }^{1,13,14}$

Despite the wide range of methods available for determining organic substances in tissues, the efficiency of lipid removal remains the most critical step. ${ }^{12,15,16} \mathrm{~A}$ sample clean-up is applied in order to remove analytical interferences and increase method sensibility, while also reducing instrument maintenance, enhancing chromatographic system performance. ${ }^{17,18}$ Traditional procedures require extract manipulation and high amounts of solvents, making them expensive and timeconsuming. In addition to being somewhat expensive, the various steps increase the possibility of losses and contamination, requiring alternatives to reduce sample manipulation. ${ }^{19}$ Among applied lipid removal methods, 
such as gel permeation chromatography (GPC), ${ }^{20-22}$ solid phase extraction $(\mathrm{SPE})^{23-25}$ and alumina columns, ${ }^{15,21}$ the accelerated solvent extraction (ASE) method emerges as an advantageous alternative, ${ }^{26-28}$ especially when coupled to in-cell purification procedures. ${ }^{28-32}$

The drawbacks of traditional extraction and clean-up procedures have stimulated the development of simple, automated, faster, cost-effective and environmentalfriendly protocols in the last decades. ${ }^{26,33-35}$ Among others, pressurized liquid extraction, or accelerated solvent extraction (ASE), is a fast low solvent consumption method for solid sample organic compound extraction, ${ }^{27}$ which has become a popular green extraction technique for various classes of organic contaminants from different kinds of samples. ${ }^{25}$ A major additional advantage of the pressurized liquid extraction method applied to biological tissues is the possibility to include a sorbent within the sealed stainless-steel cell used to extract the sample, aiming at lipid retention. This "in-cell purification" technique has been proven efficient in minimizing post-extraction cleanup steps, resulting in a single step pressured extraction combined with in-cell purification for organic compound extraction and clean-up..$^{30,31,36}$

Herein, a PAH analysis method from biological tissues based on ASE extraction and in-cell purification and optimized using two standard reference materials (fish and mussel) and fortified fish muscle (Sardinella sp.) samples is presented. In addition to complying with the basic requisites of green chemistry, namely decreased use of chemicals and hazardous residue production, the aim of this study is to provide an efficient and fast method to attend the demands for fish and shellfish PAH contamination data in emergency situations after oil spills. These data are required for decision-making regarding fisheries interruptions and seafood safety implications. ${ }^{37-39}$

\section{Experimental}

\section{Standards and chemicals}

PAH extraction recoveries from marine organism tissues were evaluated through the use of two different standard reference materials, National Institute of Standard and Technology (NIST) No. 2976 (trace elements and methylmercury in mussel tissue) and the International Atomic Energy Agency (IAEA) No. 435 (organochlorine compounds and petroleum hydrocarbons in tuna homogenate), and fortified freeze-dried sardine muscle (Sardinella sp.) samples. The sardine samples were dried to comply with the reference standard material, available as moisture-free samples.
All organic solvents used herein, methanol (CAS-No 6756-1), dichloromethane (CAS-No 75-09-2) and $n$-hexane (CAS-No 110-54-3), were gradient grade for liquid chromatography and provided by Merck (Darmstadt, Germany). The PAH standard, surrogate and internal standard were obtained from Accustandard ${ }^{\circledR}$ (New Haven, USA), as follows: PAH mix (Quebec Ministry of Environmental) H-QME-01, Z-014J Internal Standard and M-8270-SS surrogate. Sorbent materials used in in-cell extraction comprised silica gel 60 (0.063-0.200 mm) for column chromatography (CAS-No 112926-00-8; Supelco, Saint Louis, USA) and aluminum oxide 90 active neutral for column chromatography (CAS-No 1344-28-1; Supelco, Saint Louis, USA), both acquired from Merck (Rio de Janeiro, Brazil). Metallic copper (CAS-No 12069-69-1) were acquired from Vetec (Rio de Janeiro, Brazil) and sodium sulfate (CAS-No 7757-82-6) from Sigma-Aldrich (Saint Louis, USA).

\section{Tissue extraction}

Different tissue aliquots $(0.5,1.0,1.5$ and $2.0 \mathrm{~g})$ were extracted by pressurized liquid extraction ${ }^{40}$ using an ASE 300 accelerated solvent extractor system (Thermo Scientific, Bremen, Germany) system under varying pressure (1000 to $2000 \mathrm{psi}$ ) and temperature (from 80 to $150{ }^{\circ} \mathrm{C}$ ) conditions. Different $n$-hexane, dichloromethane and methanol solvent mixtures were also used. In addition, the type and amount of sorbent was also tested, with deactivated silica $(5 \% \mathrm{~m} / \mathrm{m})$ and alumina $(2 \% \mathrm{~m} / \mathrm{m})$ tested alone or in combination at different ratios. All cells volume were completed with diatomaceous earth. Blanks were analyzed in each sample batch (six samples) to demonstrate that no contamination that would affect the standard and sample analyses concerning the analytes of interest was present. A summary of the extraction procedure is presented in Figure 1.

The number of extraction cycles is another important parameter and several authors ${ }^{41-43}$ have reported that most contaminants are extracted during the first extraction. The yield of sequential cycles is much lower but, often, not negligible, and may increase the final recovery of each analyte. ${ }^{44,45}$ In order to ensure the best recovery, two and three cycles were tested.

The extracted hydrocarbons were eluted through a glass column (1.3 cm inner diameter (i.d.) and $30 \mathrm{~cm}$ height) packed with metallic copper, anhydrous $\mathrm{Na}_{2} \mathrm{SO}_{4}$, deactivated alumina $(7 \mathrm{~g}, 2 \% \mathrm{~m} / \mathrm{m})$ and silica $(10 \mathrm{~g}$, $5 \% \mathrm{~m} / \mathrm{m})$. The aromatic fractions were eluted using $75 \mathrm{~mL}$ of a dichloromethane:hexane (1:1) solution, collected after aliphatic fraction elution ( $50 \mathrm{~mL} n$-hexane). The aromatic 


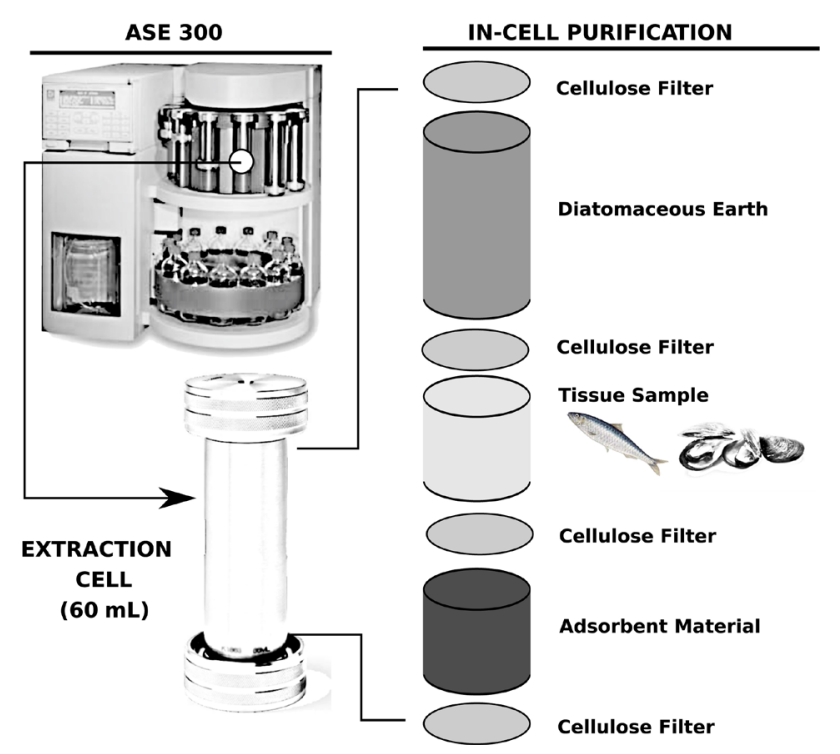

Figure 1. Accelerated solvent extraction system (ASE 300) with in-cell purification procedure.

extracts were then concentrated to $1 \mathrm{~mL}$ under a gentle $\mathrm{N}_{2}$ flow and internal standards (100 ng) were added to the samples prior to gas chromatography-mass spectrometry (GC-MS) injections.

Instrumental

PAHs quantifications were performed by gas chromatography (Thermo Trace-GC; Bremen, Germany) coupled to mass spectrometry (Thermo ITQ 900; Bremen, Germany), based on the United States Environmental Protection Agency (US-EPA) method. ${ }^{46}$ Briefly, $1 \mu \mathrm{L}$ of each extract was injected in a gas chromatography system equipped with a DB-5MS column $(30 \mathrm{~m} \times 0.25 \mathrm{~mm} \times 0.25 \mu \mathrm{m})$ at a constant flow rate $(\mathrm{He}$, $1.2 \mathrm{~mL} \mathrm{~min}^{-1}$ ) submitted to the following temperature program: $50{ }^{\circ} \mathrm{C}$ for $5 \mathrm{~min} ; 50{ }^{\circ} \mathrm{C} \mathrm{min}^{-1}$ to $80{ }^{\circ} \mathrm{C} ; 6{ }^{\circ} \mathrm{C} \mathrm{min}{ }^{-1}$ at $280{ }^{\circ} \mathrm{C}$ for $20 \mathrm{~min}$, and $12{ }^{\circ} \mathrm{C} \mathrm{min}^{-1}$ at $305^{\circ} \mathrm{C}$ for $10 \mathrm{~min}$. The ion trap mass spectrometer system operated in full scan mode $(50-550 \mathrm{~m} / \mathrm{z})$.

A calibration curve based on internal standard addition (100 ng) and at ten concentration levels (1, 2, 5, 10, 20,
50, 100, 200, 400 and $1000 \mathrm{ng} \mathrm{mL}^{-1}$ ) of 16 priority PAHs as established by the US-EPA plus dibenzothiophene, benzo[e]pyrene and perylene, was prepared. All curves with a Pearson's correlation coefficient $\left(\mathrm{R}^{2}\right)>0.99$ or higher were accepted and the homoscedasticity of the residuals from the method of least squares used in the calibration linear model was confirmed by the Cochran statistical test. Deuterated naphthalene- $d_{8}$, acenaphenene- $d_{10}$, phenanthrene- $d_{10}$, chrysene- $d_{12}$ and perylene- $d_{12}$ were used as internal standards. The compound $p$-terphenyl- $d_{14}$ was used as the surrogate standard. In addition, the limit of detection (LOD) was calculated based on the standard deviation of the response (Sy) of the curve and slope of the calibration curve $(\mathrm{S})$ at levels approximating the LOD according to the formula: $\mathrm{LOD}=3.3(\mathrm{Sy} / \mathrm{S})$, whereas the limit of quantification (LOQ) was conservatively determined based on the average mass of sample extracted and the concentration of the lowest point in the analytical curve.

\section{Results and Discussion}

Initial tests indicated no significant differences concerning pressure. Thus, this parameter was maintained at $1500 \mathrm{psi}$ throughout subsequent tests. This intermediate pressure was chosen as other authors have reported that 2000 psi results in darker extracts with broad chromatogram peaks due to coextraction with other matrix components. ${ }^{25,47}$ High pressure is applied to maintain the solvent in a liquid state far above the boiling point, with temperature comprising of the most important ASE parameters ${ }^{29}$ since it increases diffusion rates and solubilization capacity. Lastly, solvent proprieties at extraction temperature and pressure should match those of the target compounds in order to achieve efficiency.

After initial tests the main experiments were condensed to five auspicious methods to adjust extracted mass, solvent polarity, sorbent material and temperature (Table 1). Despite high temperature being a relevant factor for extraction efficiency, ${ }^{48}$ elevated values $\left(\geq 150{ }^{\circ} \mathrm{C}\right)$ were inefficient in recovering low molecular weight (LMW) PAHs $(\leq 40 \%)$. Therefore, this parameter was further tested at a lower range $\left(80-125^{\circ} \mathrm{C}\right)$.

Table 1. Adjusted method parameters for accelerated solvent extraction of marine organism tissue samples

\begin{tabular}{|c|c|c|c|c|c|c|c|c|}
\hline Test & Mass / g & Sorbent & Solvent & Temperature $/{ }^{\circ} \mathrm{C}$ & Cycles & Static time / $\min$ & Purge time / s & Rinse volume / \% \\
\hline $\mathrm{A}$ & 0.50 & alumina $20 \mathrm{~g}$ & DCM & 125 & 3 & 6 & 300 & 60 \\
\hline $\mathrm{B}$ & 3.00 & alumina $12 \mathrm{~g}$ & DCM & 125 & 2 & 6 & 300 & 60 \\
\hline $\mathrm{C}$ & 0.50 & alumina $5 \mathrm{~g}$ & DCM & 125 & 2 & 5 & 60 & 60 \\
\hline $\mathrm{D}$ & 1.00 & silica $5 \mathrm{~g}$ & DCM:M (4:1) & 80 & 3 & 10 & 90 & 75 \\
\hline $\mathrm{E}$ & 0.50 & silica $5 \mathrm{~g}$ & DCM:M (4:1) & 80 & 3 & 10 & 90 & 75 \\
\hline
\end{tabular}

DCM: dichloromethane; M: methanol. 
The results were evaluated based on compounds present in all tested matrices. Temperatures over $80{ }^{\circ} \mathrm{C}$ led to lesser recoveries of LMW compounds (Figure 2). Mean recoveries of LMW PAHs (2-3 rings) ranged from 12 to $31 \%$ in test A, 19 to $58 \%$ in test B and $55-59 \%$ in test C. On the other hand, LMW PAHs in tests D and E ranged from 60 to $76 \%$ and from 57 to $77 \%$, respectively, directly related to extraction temperature.

Tests D and E exhibited high average recovery performances for both low to high molecular weight compounds. They also presented lower standard variations among replicates, as evidenced by the calculated relative standard deviation. The results of the preliminary tests reported herein indicate that the fourth test $(\mathrm{D})$, was the most promising. Results for tests D and E were similar, with high recoveries and extract purification. The choice of test $\mathrm{D}$ is due to greater extracted masses and, therefore, less analytical bias due to sample size, as well as the potential to lower limits of quantification.

Solvent selection was the crucial first step for the development of the ASE protocols. ${ }^{49}$ Some authors ${ }^{50,51}$ have been reported the use of high-polar solvents, and that non-polar solvents can lead to lower efficiencies. This method was developed using free water samples to ensure repeatability, since water content in samples varies widely and, consequently, so does the effectively extracted tissue mass. Risks to human health due to the ingestion of contaminated food considers many variables, including fish consumption rates. ${ }^{10,42}$ Since these rates are calculated regarding the food item as it is consumed, moist, wet weight should be determined before or following the freeze-drying process or following sodium sulfate sample treatment before extraction.

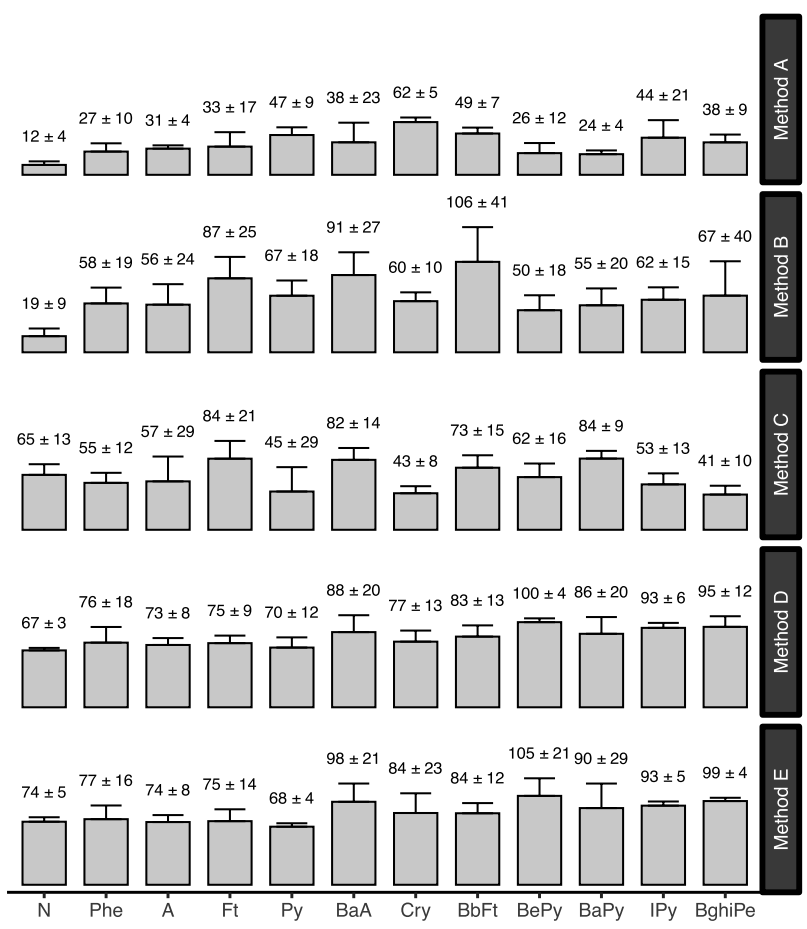

Figure 2. Mean relative recoveries and standard deviations ( $\%$, above the bars) of selected PAHs (see Table 2 for compound names), and relative standard deviations (square brackets below the bars) in all performed tests.

Based on the attained results presented in Table 1, nine NIST SRM 2976 samples were extracted through D test parameter for method validation. Figure 3 shows a typical GC-MS selected ion monitoring chromatogram obtained in the NIST analysis. This standard reference material was chosen because it has the highest lipid content, and is the most complex matrix available. Another important issue for choosing certified material over fortified samples is the reproducibility of real sample extraction. In the

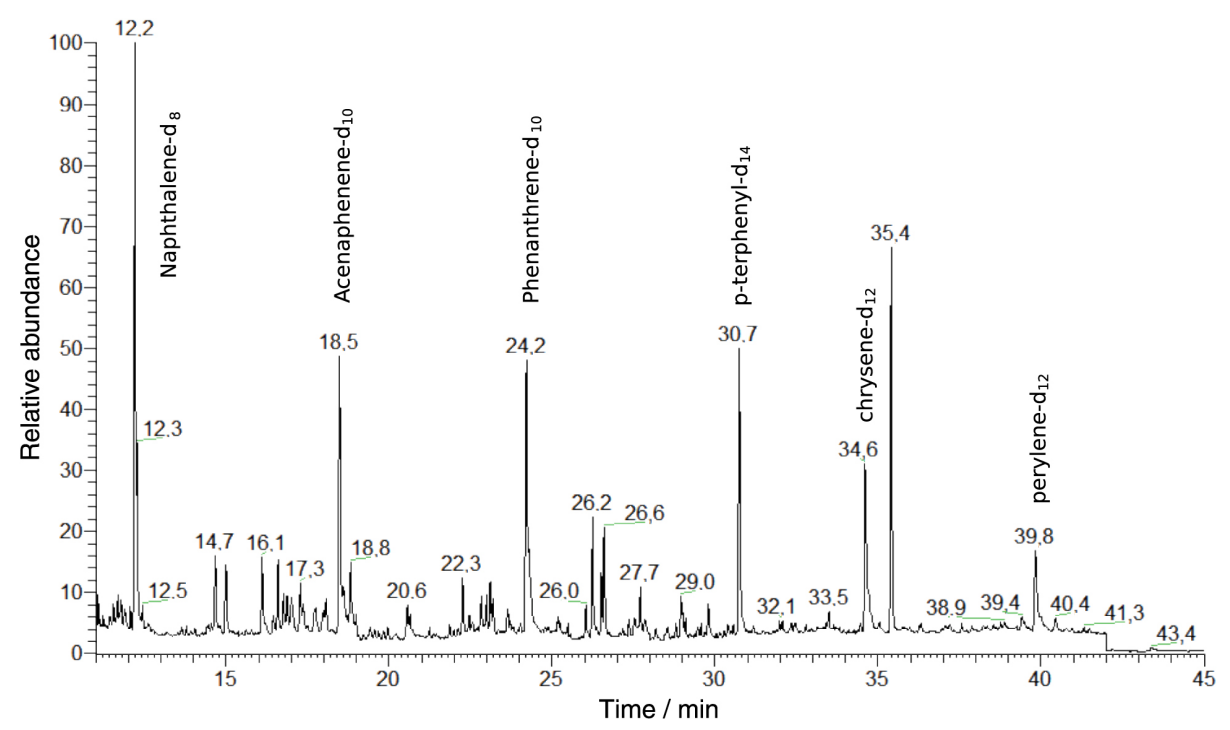

Figure 3. Example of a chromatogram obtained by GC-MS selected ion monitoring analysis of the certified reference material (NIST 2976), showing the deuterated internal standards added (see text for details). 
incremental (spike) tests, PAHs are added to the tissue samples and extracted from the tested matrix, instead of being incorporated into matrix, as in reference materials.

The proposed procedure accurately extracted PAHs from a wide concentration PAH range (1.9-225 $\left.\mathrm{ng} \mathrm{g}^{-1}\right)$ and recoveries, applied to assess method performance when investigating a particular material, ${ }^{52}$ presented excellent values (Figure 4). The mean recovery range of the SRM extracted by the developed method ranged from $69 \pm 17 \%$ (naphthalene) to $102 \pm 16 \%$ (benzo[e]pyrene), proving its efficiency. The mean and standard deviation considering all PAHs was of $83 \pm 14 \%$. The lower recovery and high relative deviation for naphthalene compared to the other determined PAHs can be attributed to its vapor pressure $\left(8.64 \mathrm{~Pa}\right.$ at $\left.20{ }^{\circ} \mathrm{C}\right)$ and consequent evaporation losses. However, despite losses through the analytical process, naphthalene still attained good recovery, within the range of the other PAHs ASE assessments, for example, 66$101 \%$ reported by Brockmeyer et al., ${ }^{48}$ and $53-93 \%$ by Wang et al..$^{53}$

(a)
In addition to good recoveries values, mean and uncertainty values were also compared to reference material uncertainties. The certified NIST value is an unweighted mean of the results from two or three analytical methods and the listed uncertainty is an expanded uncertainty of the mean. ${ }^{54}$ Reference values listed for NIST are the means of results applying one analytical technique, and the expanded uncertainty ( $U$ ) is calculated as $U=\mathrm{ku}_{\mathrm{c}}$, where $\mathrm{u}_{\mathrm{c}}$ is one standard deviation of the analyte mean, and $\mathrm{k}$ is a coverage factor. The estimated standard uncertainty of the mean, $\mathrm{u}_{\mathrm{xi}}$, is calculated by dividing the standard deviation (s) by the square root of the number of observations, ${ }^{55,56}$ herein further expanded by the $t$-value at a 95\% confidence level.

Mean and uncertainty evaluations were performed through normalized errors (Table 2), where error values lower than 1 are considered conforming or passing, and outside of this value $(\geq 1)$, nonconforming or failing. All values for the normalize errors in this research were within acceptable ranges. In addition, the calculated limits of detection (LOD) and of quantification (LOQ) obtained by

(b)

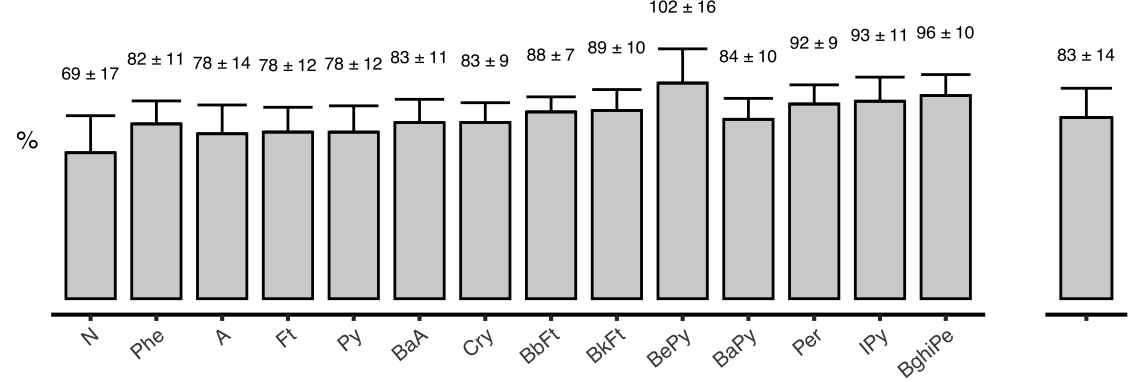

Figure 4. Individual (a) and global (b) PAHs recovery means and standard deviations from nine NIST SRM replicates extracted through the established D method parameters (see Table 2 for compound names).

Table 2. Means (x) and uncertainties (u) for the standard reference material, developed method and normalized error

\begin{tabular}{lcccc}
\hline & \multicolumn{2}{c}{ Mean / $\left(\mathrm{ng} \mathrm{g}^{-1}\right)$} & & Normalized error \\
\cline { 2 - 3 } Compound & NIST SRM 2976 & Developed method & $\left|\overline{\mathrm{x}}_{1} \pm \overline{\mathrm{x}}_{2}\right|$ & LOD/LOQ / (ng g $\left.)^{-1}\right)$ \\
& $\overline{\mathrm{x}}_{1} \pm \mathrm{u}_{1}$ & $\overline{\mathrm{x}}_{2} \pm \mathrm{u}_{2}$ & $\sqrt{\mathrm{u}_{1}^{2}+\mathrm{u}_{2}^{2}}$ & $0.02 / 0.40$ \\
\hline Naphthalene (N) & $9.68 \pm 0.61^{\mathrm{a}}$ & $6.66 \pm 3.01$ & 0.98 & $0.04 / 0.40$ \\
Phenanthrene (Phe) & $74.4 \pm 4.7^{\mathrm{b}}$ & $61.3 \pm 14.3$ & 0.87 & $0.02 / 0.40$ \\
Anthracen (A) & $2.46 \pm 0.10^{\mathrm{a}}$ & $1.94 \pm 0.59$ & 0.90 & $0.02 / 0.40$ \\
Fluoranthene (Ft) & $287 \pm 34^{\mathrm{b}}$ & $225 \pm 60$ & 0.85 & $0.04 / 0.40$ \\
Pyrene (Py) & $166 \pm 21^{\mathrm{b}}$ & $130 \pm 37$ & 0.73 & $0.06 / 0.40$ \\
Benz[a]anthracene (BaA) & $31.1 \pm 3.9^{\mathrm{b}}$ & $25.8 \pm 6.1$ & 0.81 & $0.06 / 0.40$ \\
Chrysene (Cry) & $123.6 \pm 2.9^{\mathrm{b}}$ & $106 \pm 21$ & 0.85 & $0.04 / 0.40$ \\
Benzo[b]fluoranthene (BbFt) & $41.5 \pm 2.6^{\mathrm{b}}$ & $36.5 \pm 5.24$ & 0.62 & $0.04 / 0.40$ \\
Benzo[k]fluoranthene (BkFt) & $18.95 \pm 0.54^{\mathrm{b}}$ & $16.8 \pm 3.3$ & 0.01 & $0.02 / 0.40$ \\
Benzo[e]pyrene (BePy) & $28.9 \pm 2.9^{\mathrm{b}}$ & $29.4 \pm 8.3$ & 0.86 & $0.04 / 0.40$ \\
Benzo[a]pyrene (BaPy) & $9.73 \pm 0.43^{\mathrm{b}}$ & $8.22 \pm 1.71$ & 0.50 & $0.04 / 0.40$ \\
Perylene (Per) & $6.80 \pm 0.34^{\mathrm{b}}$ & $6.23 \pm 1.09$ & 0.20 & $0.04 / 0.40$ \\
Indeno[1,2,3-cd]pyrene (IPy) & $14.9 \pm 4.5^{\mathrm{a}}$ & $13.9 \pm 3.0$ & 0.23 & $0.04 / 0.40$ \\
Benzo[ghi]perylene (BghiPe) & $23.7 \pm 2.2^{\mathrm{b}}$ & $22.7 \pm 4.2$ & \\
\hline Refence
\end{tabular}

${ }^{\mathrm{a}}$ Reference mass fraction; ${ }^{\mathrm{b}}$ certified mass fraction. LOD: limit of detection; LOQ: limit of quantification. 
the proposed method, respectively $0.02-0.04 \mathrm{ng} \mathrm{g}^{-1}$ and $0.40 \mathrm{ng} \mathrm{g}^{-1}$ for the PAH compounds included in Table 2, are well below thresholds of biota contamination and thus suitable for PAHs body burden evaluation.

\section{Conclusions}

The extraction parameters of the proposed method ensure maximum extraction efficiency, reducing extract manipulation and avoiding further purification procedures, such as gel permeation chromatography (GPC). The extraction method parameters defined throughout this research are as follows: $1 \mathrm{~g}$ of freeze-dried tissue, $5 \mathrm{~g}$ of deactivated silica (5\%), a dichloromethane:methanol solution $(4: 1 \mathrm{v} / \mathrm{v})$, a temperature of $80{ }^{\circ} \mathrm{C}$, three cycles, $10 \mathrm{~min}$ of static time, and $90 \mathrm{~s}$ of purge time. Time and reagent consumption in the developed method are about $50 \%$ less compared to traditional methods, such as Soxhlet extraction coupled to GPC purification, ${ }^{57,58}$ emphasizing the importance of this study from a green chemistry perspective.

\section{Acknowledgments}

This study was financed in part by the Coordenação de Aperfeiçoamento de Pessoal de Nível Superior Brazil (CAPES) - Finance Code 001. The authors are grateful for the financial support received in carrying out this research provided through a compensatory measure established by the Chevron Conduct Adjustment Term, conducted by the Brazilian Federal Public Ministry (MPF/RJ) and implemented through the Brazilian Fund for Biodiversity (Funbio). RSC is a research fellow from CNPq (proc. No. 309347/2017-3) and Cientista do Nosso Estado FAPERJ (proc. No. E-26/203.066/2017). The authors also thank the comments provided by three anonymous reviewers, which improved the quality of the manuscript.

\section{References}

1. Panseri, S.; Chiesa, L.; Ghisleni, G.; Marano, G.; Boracchi, P.; Ranghieri, V.; Malandra, R. M.; Roccabianca, P.; Tecilla, M.; Food Addit. Contam., Part A 2019, 36, 601.

2. Ruddiman, W. F.; Annu. Rev. Earth Planet. Sci. 2013, 41, 45.

3. Landrigan, P. J.; Fuller, R.; Acosta, N. J. R.; Adeyi, O.; Arnold, R.; Basu, N.; Baldé, A. B.; Bertollini, R.; Bose-O’Reilly, S.; Boufford, J. I.; Breysse, P. N.; Chiles, T.; Mahidol, C.; CollSeck, A. M.; Cropper, M. L.; Fobil, J.; Fuster, V.; Greenstone, M.; Haines, A.; Hanrahan, D.; Hunter, D.; Khare, M.; Krupnick, A.; Lanphear, B.; Lohani, B.; Martin, K.; Mathiasen, K. V.; McTeer, M. A.; Murray, C. J. L.; Ndahimananjara, J. D.; Perera, F.; Potočnik, J.; Preker, A. S.; Ramesh, J.; Rockström, J.; Salinas,
C.; Samson, L. D.; Sandilya, K.; Sly, P. D.; Smith, K. R.; Steiner, A.; Stewart, R. B.; Suk, W. A.; van Schayck, O. C. P.; Yadama, G. N.; Yumkella, K.; Zhong, M.; Lancet 2018, 391, 462.

4. Ramalhosa, M. J.; Paíga, P.; Morais, S.; Ramos, S.; DelerueMatos, C.; Oliveira, M. B. P. P.; Food Chem. Toxicol. 2012, 50, 162.

5. Takeuchi, I.; Miyoshi, N.; Mizukawa, K.; Takada, H.; Ikemoto, T.; Omori, K.; Tsuchiya, K.; Mar. Pollut. Bull. 2009, 58, 663.

6. Loomis, D.; Guyton, K.; Grosse, Y.; El Ghissasi, F.; Bouvard, V.; Benbrahim-Tallaa, L.; Guha, N.; Mattock, H.; Straif, K.; Lancet Oncol. 2015, 16, 891.

7. Wang, X.; Celander, M. C.; Yin, X.; Zhang, Z.; Chen, Y.; Xu, H.; Yu, X.; Xu, K.; Zhang, X.; Kanchanopas-Barnette, P.; Mar. Pollut. Bull. 2019, 294.

8. Zelinkova, Z.; Wenzl, T.; Polycyclic Aromat. Compd. 2014, 35 , 248.

9. Agency for Toxic Substances and Disease Registry (ATSDR); Toxicological Profile for Polycyclic Aromatic Hydrocarbons; U.S. Department of Health and Human Services, Public Health Service: Atlanta, GA, 1995, available at https://www.atsdr.cdc. gov/toxprofiles/tp69.pdf, accessed in July 2021.

10. Environmental Protection Agency (EPA); Emergency Planning and Community Right-to-Know Act-Section 313; Guidance for Reporting Toxic Chemicals: Polycyclic Aromatic Compounds Category; Office of Environmental Information: Washington, DC, 2001, available at https://www.epa.gov/sites/default/files/ documents/2001pacs.pdf, accessed in July 2021.

11. Schwarzenbach, R. P.; Escher, B. I.; Fenner, K.; Hofstetter, T. B.; Johnson, C. A.; Von Gunten, U.; Wehrli, B.; Science 2006, 313, 1072.

12. Zelinkova, Z.; Wenzl, T.; Polycyclic Aromat. Compd. 2015, 35 , 248.

13. Van der Oost, R.; Beyer, J.; Vermeulen, N. P. E.; Environ. Toxicol. Pharmacol. 2003, 13, 57.

14. Storelli, M. M.; Barone, G.; Perrone, V. G.; Storelli, A.; J. Food Compos. Anal. 2013, 31, 115.

15. Lourencetti, C.; Ricci, M.; J. Chromatogr. A 2020, 1619, 460944.

16. Mashroofeh, A.; Bakhtiari, A. R.; Pourkazemi, M.; Chemosphere 2015, 120, 575.

17. Tölgyessy, P.; Miháliková, Z.; Matulová, M.; Chromatographia 2016, 79, 1561.

18. Subedi, B.; Aguilar, L.; Robinson, E. M.; Hageman, K. J.; Björklund, E.; Sheesley, R. J.; Usenko, S.; TrAC, Trends Anal. Chem. 2015, 68, 119.

19. Sloan, C.; Brown, D.; Pearce, R.; Boyer, R.; Bolton, J.; Burrows, D.; Herman, D.; Krahn, M. In Techniques in Aquatic Toxicology, vol. 2; CRC Press: Boca Raton, USA, 2005.

20. Wu, J. J.; Mak, Y. L.; Murphy, M. B.; Lam, J. C. W.; Chan, W. H.; Wang, M.; Chan, L. L.; Lam, P. K. S.; Anal. Bioanal. Chem. 2011, 400, 3165 . 
21. Zhao, Z.; Zhang, L.; Cai, Y.; Chen, Y.; Ecotoxicol. Environ. Saf. 2014, 104, 323.

22. Liguori, L.; Heggstad, K.; Hove, H. T.; Julshamn, K.; Anal. Chim. Acta 2006, 573-574, 181.

23. Hong, J.; Kim, H.-Y.; Kim, D.-G.; Seo, J.; Kim, K.-J.; J. Chromatogr. A 2004, 1038, 27.

24. Sapozhnikova, Y.; Lehotay, S. J.; Anal. Chim. Acta 2013, 758, 80.

25. Sun, H.; Ge, X.; Lv, Y.; Wang, A.; J. Chromatogr. A 2012, 1237, 1.

26. Cioca, A. A.; Heemken, O.; Mihaiu, M.; Bull. Univ. Agric. Sci. Vet. Med. Cluj-Napoca, Vet. Med. 2017, 74, 55.

27. Richter, B. E.; Jones, B. A.; Ezzell, J. L.; Porter, N. L.; Avdalovic, N.; Pohl, C.; Anal. Chem. 1996, 68, 1033.

28. Choi, M.; Lee, I. S.; Jung, R. H.; Food Chem. 2016, $205,1$.

29. Pintado-Herrera, M. G.; González-Mazo, E.; Lara-Martín, P. A.; J. Chromatogr. A 2016, 1429, 107.

30. Vazquez-Roig, P.; Picó, Y.; TrAC, Trends Anal. Chem. 2015, 71,55 .

31. Andreu, V.; Picó, Y.; TrAC, Trends Anal. Chem. 2019, 118, 709.

32. Abou-Elwafa Abdallah, M.; Drage, D.; Harrad, S.; Environ. Sci.: Processes Impacts 2013, 15, 2279.

33. de Koning, S.; Janssen, H. G.; Brinkman, U. A. T.; Chromatographia 2009, 69, 33.

34. Dodds, E. D.; McCoy, M. R.; Geldenhuys, A.; Rea, L. D.; Kennish, J. M.; J. Am. Oil Chem. Soc. 2004, 81, 835.

35. Nording, M.; Nichkova, M.; Spinnel, E.; Persson, Y.; Gee, S. J.; Hammock, B. D.; Haglund, P. In Analytical and Bioanalytical Chemistry, vol. 385; Springer: Berlin, Germany, 2006.

36. Guo, J.; Li, Z.; Sandy, A. L.; Li, A.; J. Chromatogr. A 2014, $1370,1$.

37. Farrington, J. W.; Mar. Pollut. Bull. 2020, 150, 110744.

38. Gohlke, J. M.; Doke, D.; Tipre, M.; Leader, M.; Fitzgerald, T.; Environ. Health Perspect. 2011, 119, 1062.

39. Yender, R.; Michel, J. M.; Lord, C.; Managing Seafood Safety after an Oil Spill; Hazardous Materials Response Division, Office of Response and Restoration, National Oceanic and Atmospheric Administration: Seattle, 2002, available at https:// www.irrd.org/wp-content/uploads/2019/10/NOAA-2002Novmanaging-seafood-safety-oil-spill.pdf, accessed in July 2021.

40. EPA Method 3545A (SW-846): Pressurized Fluid Extraction (PFE); U.S. EPA: Washington DC, 2007, available at https:// www.epa.gov/esam/method-3545a-sw-846-pressurized-fluidextraction-pfe, accessed in July 2021.

41. Gómez-Ariza, J. L.; Bujalance, M.; Giráldez, I.; Velasco, A.; Morales, E.; J. Chromatogr. A 2002, 946, 209.

42. Rodrigues, E. T.; Pardal, M. Â.; Salgueiro-González, N.; Muniategui-Lorenzo, S.; Alpendurada, M. F.; J. Chromatogr. A 2016, 1452, 10.
43. Zhang, Q.; Liu, Y.; Han, G.; Liang, T.; Okoli, C. P.; Anal. Methods 2019, 11, 1483.

44. Subedi, B.; Usenko, S.; J. Chromatogr. A 2012, 1238, 30.

45. Pinto, M. I.; Micaelo, C.; Vale, C.; Sontag, G.; Noronha, J. P.; Arch. Environ. Contam. Toxicol. 2014, 67, 547.

46. EPA Method 8270D: Semivolatile Organic Compounds by Gas Chromatography/Mass Spectrometry (GC/MS); U.S. EPA: Washington DC, 2007, available at https://archive.epa.gov/epa/ sites/production/files/2015-12/documents/8270d.pdf, accessed in July 2021.

47. Reindl, S.; Höfler, F.; Anal. Chem. 1994, 66, 1808.

48. Brockmeyer, B.; Kraus, U. R.; Theobald, N.; Environ. Sci. Pollut. Res. 2015, 22, 19887.

49. Chen, W.; Liu, Y.; Song, L.; Sommerfeld, M.; Hu, Q.; Algal Res. 2020, 51, 102080.

50. Björklund, E.; Nilsson, T.; Bøwadt, S.; TrAC, Trends Anal. Chem. 2000, 19, 434.

51. Saim, N.; Dean, J. R.; Abdullah, P. M.; Zakaria, Z.; Anal. Chem. 1998, 70, 420.

52. International Atomic Energy Agency (IAEA); Development and Use of Reference Materials and Quality Control Materials; IAEA: Viena, Austria, 2003, available at https://www-pub.iaea. org/MTCD/Publications/PDF/te_1350_web.pdf, accessed in July 2021.

53. Wang, G.; Lee, A. S.; Lewis, M.; Kamath, B.; Archer, R. K.; J. Agric. Food Chem. 1999, 47, 1062.

54. Taylor, B. N.; Kuyatt, C. E.; NIST Technical Note 1297 Guidelines for Evaluating and Expressing the Uncertainty of NIST Measurement Results; National Institute of Standards and Technology: Gaithersburg, MD, 1994, available at http:// emtoolbox.nist.gov/Publications/NISTTechnicalNote1297s. pdf, accessed in July 2021.

55. Stant, L. T.; Aaen, P. H.; Ridler, N. M.; J. Int. Meas. Confed. 2016, $94,847$.

56. Joint Committee for Guides in Metrology; Evaluation of Measurement Data Guide to the Expression of Uncertainty in Measurement, 2008, available at https://ncc.nesdis.noaa.gov/ documents/documentation/JCGM_100_2008_E.pdf, accessed in July 2021.

57. Itoh, N.; Numata, M.; Aoyagi, Y.; Yarita, T.; Anal. Chim. Acta 2008, 612, 44 .

58. Jánská, M.; Tomaniová, M.; Hajšlová, J.; Kocourek, V.; Anal. Chim. Acta 2004, 520, 93

Submitted: April 20, 2021

Published online: July 28, 2021 